\title{
EFFECT OF SOME PRE AND POSTHARVEST TREATMENTS ON QUALITY AND STORABILITY OF GREEN ONION
}

\author{
MOHAMED, OMAIMA O. and AMAL S.H. ATRESS
}

Postharvest and Handling of Vegetable Crops Department, Horticulture Research Institute, Agricultural Research Center, Giza, Egypt.

(Manuscript received 17 May 2016)

\begin{abstract}
$\mathrm{T}$ his experiment was carried out during the winter seasons of 2014/2015 and 2015/2016 at the Agriculture Research Farm, El-Kassasien Hort. Res. Station, Ismalia Governorate, Egypt, to clarify the effects of different plant densities, $5 \mathrm{~cm}$ on one side (33 plant $\left./ \mathrm{m}^{2}\right), 2.5 \mathrm{~cm}$ on one side $\left(66\right.$ plant $\left./ \mathrm{m}^{2}\right), 5 \mathrm{~cm}$ on both sides $\left(66\right.$ plant $\left./ \mathrm{m}^{2}\right)$, and $2.5 \mathrm{~cm}$ on both sides $\left(133\right.$ plant $\left./ \mathrm{m}^{2}\right)$ on quality parameters and yield of green onion plants (Allium cepa L.), Cv. Giza 6 grown under sandy soil conditions, and also to study the impact of hydro-cooling and packaging green onion plants in polypropylene pouches on the quality parameters of green onion during storage at $3^{\circ} \mathrm{C} \pm$ 1and $95 \% \mathrm{RH}$ for 15 days. The obtained data indicated that sowing green onion seeds at low density $5 \mathrm{~cm}$ on one side (33 plant $/ \mathrm{m}^{2}$ ) significantly increased plant weight, bulb diameter, neck diameter, bulb length, and total dry weight per plant in both seasons of study as compared to other treatments. Meanwhile, higher plant density $2.5 \mathrm{~cm}$ on both sides (133 plant $/ \mathrm{m}^{2}$ ) significantly increased total yield per fed., Regarding, storage experiment, the obtained results showed, that there were a considerable and a continuous increase in weight loss $\%$, leave extension, root development, and curvature of green onion stem as the storage period was extended. On the other hand, a significant decline happened in general appearance, chlorophyll content, and TSS\% as the storage period increased. The combination between hydro-cooling and packaging, effectively maintained green onion plants with fresh appearance and acceptable sensory quality for 10 days at $3^{\circ} \mathrm{C} \pm 1$ and $95 \% \mathrm{RH}$.
\end{abstract}

\section{INTRODUCTION}

Green onion (Allium cepa L.) is one of the most important crops in Egypt used for local consumption and also as exportation commodity. Green onion is immature forms of white onion planted at high density. The most commonly maturity indices of green onion are size of the plant and bulb diameter (Technical Bulletin 2004).

Plant spacing affects plant growth and yield due to increased competition with increased plant population. Moreover, the optimum plant population differs with the availability of soil moisture, relative humidity and nutrients. Higher plant population i.e. close plant spacing reduced plant growth and yield components but increased yield per unit area (Wanns et al., 1986). 
Plant spacing influences the growth and yield of garlic. Yield of garlic is dependent on the number of plants accommodated per unit area of land. Planting of garlic at proper spacing also increases the yield and improves the grade of bulbs. Wider spacing increased number of leaves and greater plant height has been reported by Om and Srivastava, (1977).

Garlic bulb yield increases with decrease in plant density and this has been shown to correlate with the percentage of light interception by the crop leaf canopy (Brewster, 1994). The higher yield and better control of over or under bulb size could be obtained if plants are grown at optimum density. Bulb neck diameter, mean bulb weight and plant height decreased as population density increased. Total bulb yield of onion can be increased as population density increases (Kantona et al., 2003).

Intra-row spacing of $10 \mathrm{~cm}$ was superior in plant height, leaf number per plant, leaf biomass yield, leaf dry matter content and percentage of bolters of onion plant. Highest total bulb yield was recorded at the closest intra-row spacing $(5 \mathrm{~cm})$ followed by $7.5 \mathrm{~cm}$. Average gulp weight increased with increasing intra row spacing (Kahsay et al., 2013). Many of the parameters like number of leaves per plant at 56 days after emergence, plant height, leaf number, and leaf length and yield bio mass were significantly affected due to the intra raw spacing difference. When the distance between garlic plants increased the yield related parameters were increased (Hussen et al., 2014).

Green onion is a highly perishable crop due to high moisture content, high respiration rate and short shelf life. The challenges faces green onion plants after harvest are wilting, extension (roots and leaves), curvature, yellowing, and decay. Temperature management is essential to maintain green onion quality after harvest and during storage. Precooling is recommended procedure to reduce respiration rate, extend storage life sufficiently for shipping and retailing, protect produce quality and reducing losses by decreasing the rates of water loss and decay. Hydro-cooling is a cheapest and fastest cooling method. It is appropriate and effective method for cooling wide range of commodities that are not sensitive to wetting, such as green onion, celery, beet, radish, spinach, cantaloupe and carrot, and may also rehydrate slightly wilted reduce (Steven et al., 1988, Sullivan, et al., 1996, Fricke 2006, and Kitinoja and Thompson 2010). Previous studies were conducted to study the effect of different cooling methods and different packaging materials on the sensory quality of several crops and they found that, hydro-cooling retarded wilting of parsley leaves for 7 days storage at $5^{\circ} \mathrm{C}$ (Niyomlao 2000), and maintained appearance, freshness, chlorophyll content and extended shelf life for Chinese kale. (Alvares et al., 2007).

Modified atmosphere packaging for storage and transportation of fruits and vegetables is commonly achieved by packing them in plastic films such as 
polyethylene or polypropylene bags which in turn create modified atmosphere to reduce respiration and transpiration rate and reduce water loss, maintain quality and extend shelf life of produce Kader (1986).

This work was conducted to study the effect of different plant density on the yield and its component of green onion, and also studding the effect of hydro-cooling and packaging on quality attributes of green onion during storage at $3^{\circ} \mathrm{C} \pm 1$ and $95 \%$ $\mathrm{RH}$ for 15 days.

\section{MATERIALS AND METHODS}

\section{Field experiment:}

This experiment was carried out during the winter seasons of 2014/2015 and 2015/2016 at the Agriculture Research Farm, El-Kassasien Hort. Res. Station, Ismalia Governorate, Egypt, to clarify the effects of plant density on growth, physical characters and yield of green onion plants (Allium cepa L.) grown under sandy soil conditions.

The experimental soil was sandy in texture with 96.5 and $95.6 \%$ sand, 1.7 and $1.6 \%$ silt, 1.8 and $2.8 \%$ clay, 8.1 and $8.1 \mathrm{pH}, 0.03$ and $0.08 \%$ organic matter, 5.4 and $6.9 \mathrm{ppm} \mathrm{N}, 5.5$ and $6.2 \mathrm{ppm} \mathrm{P}$ and 52 and $64 \mathrm{ppm} \mathrm{K}$ in the $1^{\text {st }}$ and $2^{\text {nd }}$ seasons, respectively.

This experiment included four treatments as follow:

1-Sowing seeds at $5 \mathrm{~cm}$ on one side (33 plant $/ \mathrm{m}^{2}$ )

2- Sowing seeds at $2.5 \mathrm{~cm}$ on one side ( $66 \mathrm{plant} / \mathrm{m}^{2}$ )

3- Sowing seeds at $5 \mathrm{~cm}$ on both sides ( $66 \mathrm{plant} / \mathrm{m}^{2}$ )

4- Sowing seeds at $2.5 \mathrm{~cm}$ on both sides (133 plant $/ \mathrm{m}^{2}$ )

These treatments were distributed in a randomized complete block design with three replications.

The plot area was $10.8 \mathrm{~m}^{2}$, every plot consisted of three rows $6 \mathrm{~m}$ in length and $60 \mathrm{~cm}$ in width. Onion seeds were sown on September $21^{\text {st }}$ and $26^{\text {th }}$ in 2014 and 2015 seasons, respectively. One dripper line $\left(3.6 \mathrm{~m}^{2}\right)$ was used to measure vegetative growth traits and the other two dripper lines $\left(7.2 \mathrm{~m}^{2}\right)$ were used for estimating yield and its components.

Mineral nitrogen was applied at a rate of $90 \mathrm{Kg} \mathrm{N} /$ fed. As ammonium sulfate $(20.6 \% \mathrm{~N})$, at five equal portions during soil preparation, after $30,45,60$, and 75 days from sowing. All plots received equal amounts of compost at a rate of $30 \mathrm{~m}^{3} /$ feddan during soil preparation, the other recommended agricultural practices for commercial onion production were followed.

Onion seeds of cv. Giza 6 were obtained from Field Crops Institute, Agriculture Research Center, Egypt. 
Data Recorded: The obtained data in this study were as follows:

\section{Morphological Characters:}

A random sample of five plants from every experimental unit was taken after 115 days from sowing to investigate the following growth parameters: Plant height $(\mathrm{cm})$, number of leaves /plant, neck diameter $(\mathrm{cm})$, bulb diameter $(\mathrm{cm})$ and bulb length (cm).

Total chlorophyll: was measured in fresh leaves by using Minolta chlorophyll meter SPAD-501as SPAD units.

Total soluble solids (TSS) \%: It was determined by using a hand Refractometer according to the methods mentioned in A.O.A.C. (1990).

\section{Dry weight:}

The different parts of onion plant; i.e., leaves and bulb were oven dried at $70{ }^{\circ} \mathrm{C}$ till constant weight and then the total plant dry weight / plant were recorded.

\section{Yield and Its Components:}

At harvesting time (about 120 days after sowing) all plants from each plot were harvested to measure plant weight $(\mathrm{g})$, yield/plot $(\mathrm{kg})$ and total yield / fad. $(\mathrm{kg})$.

\section{Storage Experiment:}

\section{Plant material and treatments:}

Green onion (Allium cepa L.) cv. Giza 6 plants resulted from higher plant density $2.5 \mathrm{~cm}$ in both sides because of its higher total yield and its bulb diameters suitable for European exporter markets $1.7-1.8 \mathrm{~cm}$. were harvested, after 120 days of sowing when they reached the proper diameters and immediately transported to the laboratory within 2 hours, and kept overnight at $3 \pm 1{ }^{\circ} \mathrm{C}$ and $95 \% \mathrm{RH}$. The following morning, green onion plants graded to select plants with $1-1.5 \mathrm{~cm}$. in diameter, and dry outer leaves surrounded the bulb were removed. After that plants were divided into two groups. The first group, hydro-cooled plants immersed in a mixture of water and crushed ice for $15 \mathrm{~min}$. to pull the temperature dawn to about $4-5 \mathrm{C}^{\circ}$. Meanwhile the second group left without hydro-cooling. Hydro-cooled plants placed on absorbent paper to remove the excess surface water, after that green leaves of both hydro-cooled and non hydro-cooled plants were trimmed to $23 \mathrm{~cm}$ with sharp knife and roots were also ait with a sharp scissors. Half of hydro-cooled and none hydro-cooled plants packed in polypropylene pouches sealed in the top and unsealed from the bottom with thickness of 30 micron and the other left non - packed as follows:

1- Hydro-cooled and packed plants.

2- Non hydro-cooled and packed plants.

3- Hydro-cooled and non packed plants.

4- Non hydro-cooled and non packed plants. 
Six green onion plants weighing about $120 \mathrm{gm}$ bunched together with a rubber band and put in a carton boxes at the dimensions of $27 * 34 * 8 \mathrm{~cm}$ and every carton box contain about 6 bunches as one replicate, nine replications for each treatment were stored at $3 \pm 1 \mathrm{C}^{\circ}+95 \% \mathrm{RH}$ for 15 days. After 5 days storage 6 plants from each treatment was taken at random in three replications and arranged in a complete randomized design. Samples were evaluated for the changes in the quality parameters during storage every 5 days.

\section{The following data were recorded:}

1. Weight loss percentage (estimated according to the following equation:

Initial plant weight - plant weight at sampling date

Weight loss $\%=$ $\mathrm{X} 100$

Initial plant weight

2. General appearance was determined according to the following score system: $9=$ excellent, $7=$ good, $5=$ fair, $3=$ poor, and $1=$ unusable. This scale depends on morphological defects such as leaves wilting, and leaves discoloration

3. Leaf extension or "telescoping" of inner green onion plants $(\mathrm{mm})$ were measured on each individual plant from the surface of the leaf base to the end of most extended portion with a vernier caliper.

4. Curvature score of $1-5$ was used, where 1 , none; 2 , curvature of stem or leaf up to $15^{\circ}$ from the horizontal, $3=15-30^{\circ}, 4=30-45^{\circ}$ and $5.45^{\circ}$ from horizontal (Hong et al., 2000)

5. Roots developments $(\mathrm{mm})$ were measured on each individual plant with a vernier caliper.

6. Total soluble solids (TSS) \%: It was determined by using a hand Refractometer according to the methods mentioned in A.O.A.C. (1990).

All quality parameters were monitored before and every 5 days during storage.

7. Total chlorophyll: was measured in fresh leaves by using Minolta chlorophyll meter SPAD-501as SPAD units.

\section{Statistical Analysis:}

Data of the field experiment and cold storage experiment were statistically analyzed by using MSTAT statistical software and the treatments means were compared by using LSD at 0.05 level of probability according to Snedecor and Cochran (1980). The data were tabulated and statistically analyzed according a randomized complete block design for field experiment and complete randomized design for storage experiment. 


\section{RESULTS AND DISCUSSION}

\section{The field experiment}

\section{Morphological characters:}

Data presented in Table 1 reveal that plant density obtained a promotive effect on morphological characters of green onion plants expressed as plant height, number of leaves per plant and total chlorophyll in leaves but such increment did not reach to the statistical level, while, planting seeds of green onion at $5 \mathrm{~cm}$ on one side significantly increased total dry weight per plant in both seasons of study as compared to other treatments. Singh and Sachan (1999) reported on garlic and onion that the greatest number of leaves per plant was found in the widest spacing. This could be partly due to the fact that wider spaced plants produce more axial branching than plants spaced at closer spacing.

The increment in total dry weight may be attributed to the fact that wider plant spacing showed less competitive for water, sun light, space and essential minerals (El-Seifi et al.,2014). As a result the plant develops to a larger size and larger yield bio mass.

From the above mentioned results it could be concluded that, the plants grown under wider spaces received more nutrients, light and moisture around each plant compared to plants in closer spaces which is probably the cause of better performance of total fresh weight of individual onion plants in wider spaces. Present results are confirmed by the findings of Kantona et al., 2003 and Kahsay et al., 2013 on onion and Brewster, 1994 and Hussen et al., 2014 on garlic.

\section{Physical characters of green onion bulbs}

Results in Table 2 demonstrate the effect of plant density on physical characters of green onion bulbs; i.e., bulb diameter, neck diameter and bulb length. Such data indicate that planting seeds of green onion at $5 \mathrm{~cm}$ on one side significantly increased bulb diameter in both seasons of study as compared to other treatments. These increases were used in connection with the decreased inter plant competition that leads to increased plant capacity, for utilizing the environmental inputs in building great amount of metabolites to be used in developing new tissues and increasing its yield components (Dahmardeh et al., 2010). 
Table1. Effect of plant density on morphological characters of green onion plants during 2014/2015 and 2015/2016 seasons

\begin{tabular}{|c|c|c|c|c|c|c|c|c|}
\hline \multirow{3}{*}{ Characters } & \multicolumn{8}{|c|}{ Morphological characters / plant } \\
\hline & \multicolumn{2}{|c|}{$\begin{array}{l}\text { Plant height } \\
\qquad(\mathrm{cm})\end{array}$} & \multicolumn{2}{|c|}{ No. of leaves } & \multicolumn{2}{|c|}{ Dry weight (g) } & \multicolumn{2}{|c|}{ Chl.content (SPAD unit) } \\
\hline & $1^{\text {st }}$ season & $2^{\text {nd }}$ season & $1^{\text {st }}$ season & $2^{\text {nd }}$ season & $1^{\text {st }}$ season & $2^{\text {nd }}$ season & $1^{\text {st }}$ season & $2^{\text {nd }}$ season \\
\hline $5 \mathrm{~cm}$ on one side & 54.0 & 56.3 & 5.3 & 5.3 & 2.06 & 2.13 & 57.36 & 57.00 \\
\hline $2.5 \mathrm{~cm}$ on one side & 52.0 & 55.0 & 5.3 & 5.0 & 1.77 & 1.68 & 56.85 & 56.90 \\
\hline $5 \mathrm{~cm}$ on both sides & 52.7 & 52.3 & 5.3 & 5.0 & 1.61 & 1.56 & 55.06 & 55.78 \\
\hline $2.5 \mathrm{~cm}$ on both sides & 49.3 & 48.7 & 4.7 & 4.7 & 1.52 & 1.48 & 54.79 & 55.69 \\
\hline L.S.D at 0.05 level & N.S & N.S & N.S & N.S & 0.25 & 0.32 & N.S & N.S \\
\hline
\end{tabular}


On the other side, all plant density treatments did not reflect any significant effect on neck diameter and bulb length. The obtained results are in harmony with those of Kantona et al., 2003 on garlic.

\section{Yield and its components of green onion plants}

Results in Table 3 show the effect of plant density on yield and its components of green onion plants. Generally, it is obvious from the data that planting seeds of green onion at $5 \mathrm{~cm}$ on one side was the most favorable treatment for enhancing plant weight (34.39 and 35.05g), on the contrary, planting seeds of green onion at $2.5 \mathrm{~cm}$ on both sides recorded the lowest values of plant weight (19.64 and $20.13 \mathrm{~g}$ ) in the first and second seasons, respectively. This result may be attributed to the fact that wider plant spacing showed less competitive for water, sun light, space and essential minerals. As a result plant development to a larger size and larger yield.

Regarding yield per plot and total yield per feddan, it is clear from the same data that maximum yield per plot ( 28.3 and $29.0 \mathrm{~kg}$ ) and total yield per fed.(10.999 and $11.273 \mathrm{~kg}$ ) were obtained from the higher planting density at $2.5 \mathrm{~cm}$ on both sides and minimum yield per plot (12.4 and $12.6 \mathrm{~kg}$ ) and total yield per fed.(4815 and $4907 \mathrm{~kg}$ ) were found at the lower planting density at $5 \mathrm{~cm}$ on one side in both seasons of study. The increasing in yield per plot and total yield per fed. due to increasing number of plants/unit area.

These results are in accordance with those of Kantona et al., 2003 and Kahsay et al., 2013 on onion and Brewster, 1994 and Hussen et al., 2014 on garlic.

As for total soluble solids TSS\%, it is clear from the data in Table 3 that, all plant density treatments did not reflected any significant effect on TSS of green onion bulbs.

Table 2. Effect of plant density on physical characters of green onion bulbs during $2014 / 2015$ and $2015 / 2016$ seasons

\begin{tabular}{|l|l|l|l|l|l|l|}
\hline \multirow{2}{*}{ Characters } & \multicolumn{5}{c|}{ Physical characters of bulbs } \\
\cline { 2 - 7 } & \multicolumn{2}{|c|}{$\begin{array}{c}\text { Bulb diameter } \\
(\mathrm{cm})\end{array}$} & \multicolumn{2}{c|}{ Neck diameter $(\mathrm{cm})$} & \multicolumn{2}{c|}{ Bulb length $(\mathrm{cm})$} \\
\cline { 2 - 7 } & $1^{\text {st }}$ season & $\begin{array}{c}2^{\text {nd }} \\
\text { season }\end{array}$ & $\begin{array}{c}1^{\text {st }} \\
\text { season }\end{array}$ & $\begin{array}{c}2^{\text {nd }} \\
\text { season }\end{array}$ & $\begin{array}{c}1^{\text {st }} \\
\text { season }\end{array}$ & $2^{\text {nd }}$ season \\
\hline $5 \mathrm{~cm}$ on one side & 2.33 & 2.43 & 1.53 & 1.77 & 4.53 & 4.47 \\
\hline $2.5 \mathrm{~cm}$ on one side & 1.90 & 1.97 & 1.33 & 1.60 & 4.27 & 4.37 \\
\hline $5 \mathrm{~cm}$ on both sides & 1.87 & 1.93 & 1.33 & 1.43 & 4.17 & 4.20 \\
\hline $2.5 \mathrm{~cm}$ on both sides & 1.83 & 1.70 & 1.27 & 1.23 & 4.30 & 4.27 \\
\hline L.S.D at 0.05 level & 0.43 & 0.46 & N.S & N.S & N.S & N.S \\
\hline
\end{tabular}


Table 3. Effect of plant density on yield and its components of green onion plants during 2014/2015 and 2015/2016 seasons.

\begin{tabular}{|c|c|c|c|c|c|c|c|c|}
\hline \multirow[b]{3}{*}{ Treatments } & \multicolumn{8}{|c|}{ yield and its components } \\
\hline & \multicolumn{2}{|c|}{$\begin{array}{l}\text { Plant weight } \\
\text { (g) }\end{array}$} & \multicolumn{2}{|c|}{$\begin{array}{l}\text { Yield/plot } \\
\text { (kg) }\end{array}$} & \multicolumn{2}{|c|}{ Total yield/fed. (kg) } & \multicolumn{2}{|c|}{ TSS\% } \\
\hline & $1^{\text {st }}$ season & $2^{\text {nd }}$ season & $1^{\text {st }}$ season & $2^{\text {nd }}$ season & $1^{\text {st }}$ season & $2^{\text {nd }}$ season & $1^{\text {st }}$ season & $2^{\text {nd }}$ season \\
\hline $5 \mathrm{~cm}$ on one side & 34.39 & 35.05 & 12.4 & 12.6 & 4815 & 4907 & 12.0 & 12.8 \\
\hline $2.5 \mathrm{~cm}$ on one side & 29.46 & 29.08 & 21.2 & 20.9 & 8249 & 8143 & 12.3 & 13.0 \\
\hline $5 \mathrm{~cm}$ on both sides & 25.20 & 25.24 & 18.1 & 18.2 & 7056 & 7067 & 13.0 & 13.3 \\
\hline $2.5 \mathrm{~cm}$ on both sides & 19.64 & 20.13 & 28.3 & 29.0 & 10999 & 11273 & 13.0 & 13.7 \\
\hline L.S.D at 0.05 level & 2.74 & 6.47 & 1.9 & 7.0 & 738 & 2705 & N.S & N.S \\
\hline
\end{tabular}




\section{The storage experiment:}

\section{Weight loss \%:}

As shown in Table 4 there is a considerable and a continuous increase in weight loss $\%$ as the storage period was extended. This continuous loss in weight during storage resulted from the loss of water by transpiration and dry matter by respiration (Atta- Aly 1998 and Emam1999) on green onion. Regarding treatments, weight loss \% significantly declined in hydro-cooled and packed green onion followed by packed and non hydro-cooled plants which displayed less than $6 \%$ and $5 \%$ loss in weight after 15 days storage at $3 \pm 1$ and $95 \% \mathrm{RH}$ in the first and second season respectively, as compared with other treatments.

On contrast, non hydro-cooled and non packed plants (control) recorded the highest value of weight loss \%. Moreover, the visual wilting of leaves was noticed in control treatment after 10 days of storage in both seasons. The interaction between treatments and storage periods reveal that the combination between hydro-cooling and packaging effectively maintained the freshness of green onion plants. This result may be due to the positive effects of hydro-cooling and polypropylene (PP) packaging in reducing respiration and transpiration rates which in turn reduce water loss. Such results were supported by Atta- Aly (1998), in hydro-cooled green onion and Rahman et al., (2012) who packed green chili (Capsicum annuum ) in polypropylene packets with thickness of 33 micron and found that $(\mathrm{pp})$ packets conserved moisture, reduced weight loss and prevent shrinkage of green chili as compared to chili kept in bulk without packaging.

\section{General appearance:}

Visual appearance was included morphological defects occurs in green onion plants during storage such as wilting and leaf discoloration. Table 4 indicated that there was a significant decline in visual appearance of fresh cut green onion as well as the storage period was prolonged. 
Table 4. Effect of hydrocooling and packaging on weight loss \% and general appearance of green onion during storage period in 2014/2015 and 2015/2016 seasons.

\begin{tabular}{|c|c|c|c|c|c|c|c|c|c|c|}
\hline \multirow{4}{*}{ Treatments $(T)$} & \multicolumn{10}{|c|}{ Weight loss $\%$} \\
\hline & \multicolumn{5}{|c|}{ Season $2014 / 2015$} & \multicolumn{4}{|c|}{ Season $2015 / 2016$} & \\
\hline & \multicolumn{10}{|c|}{ Storage period in days (S) } \\
\hline & 0 & 5 & 10 & 15 & Mean & 0 & 5 & 10 & 15 & Mean \\
\hline \multirow{4}{*}{$\begin{array}{l}\text { Hydrocooled and packed } \\
\text { Hydrocooled and non packed } \\
\text { Nonh ydrocooled and packed } \\
\text { Non hydrocooled andnon packed }\end{array}$} & - & 0.61 & 1.28 & 2.17 & 1.36 & - & 0.79 & 0.92 & 1.55 & 1.09 \\
\hline & - & 4.05 & 7.35 & 11.82 & 7.74 & - & 4.00 & 7.30 & 12.90 & 8.07 \\
\hline & - & 3.26 & 3.40 & 5.52 & 4.06 & - & 3.57 & 3.57 & 5.73 & 4.29 \\
\hline & - & 5.71 & 8.37 & 12.97 & 9.02 & - & 5.98 & 8.68 & 13.13 & 9.24 \\
\hline Mean & - & 3.41 & 5.10 & 8.12 & - & & 3.57 & 5.12 & 5.33 & - \\
\hline \multirow[t]{2}{*}{ LSD at 0.05 level } & $T=0.62$ & $S=0.53$ & $\mathrm{~T} * \mathrm{~S}$ & 1.07 & & & & $\mathrm{~T}=0.7$ & $\mathrm{~S}=$ & $\mathrm{T} * \mathrm{~S}=1.29$ \\
\hline & \multicolumn{10}{|c|}{ General Appearance score* } \\
\hline \multirow{4}{*}{$\begin{array}{l}\text { Hydrocooled and packed } \\
\text { Hydrocooled and non packed } \\
\text { Nonh ydrocooled and packed } \\
\text { Non hydrocooled andnon packed }\end{array}$} & 9.00 & 9.00 & 8.67 & 7.67 & 8.58 & 9.00 & 9.00 & 8.33 & 7.33 & 8.42 \\
\hline & 9.00 & 8.67 & 6.00 & 4.33 & 7.00 & 9.00 & 8.33 & 5.67 & 3.67 & 6.67 \\
\hline & 9.00 & 9.00 & 8.00 & 6.00 & 8.00 & 9.00 & 9.00 & 7.33 & 5.33 & 7.67 \\
\hline & 9.00 & 7.00 & 5.67 & 3.67 & 6.33 & 9.00 & 7.00 & 5.00 & 4.00 & 6.25 \\
\hline Mean & 9.00 & 8.42 & 7.08 & 5.42 & - & 9.00 & 8.33 & 6.58 & 5.08 & - \\
\hline LSD at 0.05 level & $\mathrm{T}=0.55$ & $S=0.55$ & $\mathrm{~T} * \mathrm{~S}$ & 1.10 & & $T=c$ & $\begin{array}{ll}31 \mathrm{~S} \\
\mathrm{~S}=\end{array}$ & $\begin{array}{l}=0.31 \\
0.63\end{array}$ & & \\
\hline
\end{tabular}

* Score: $9=$ Excellent, $7=$ Good, $5=$ Fair, $3=$ Poor 
This decline due to the morphological defects occurs in green onion during storage such as wilting, leaf discoloration, leaf curvature and leaf growth extension (Hong et al., 2000). The combination between hydro-cooling and polypropylene packaging (PP) extended shelf life, improved freshness and displayed the green onion plants with good appearance until 15 days storage at $3 \pm 1$ and $95 \% \mathrm{RH}$. Meanwhile, packing green onion plants in polypropylene package without hydro-cooling also, showed good appearance after 10 days storage and acceptable appearance after 15 days as compared with the other treatments which displayed poor appearance by the end of storage. These results indicated that packaging is the main factor affecting green onion appearance and shelf life. The interaction between treatments and storage period reveal that the combination between hydro-cooling and packaging significantly maintained freshness and good appearance during all storage periods as compared with other treatments.

\section{Curvature:}

Curvature is a common defect in the commercial green onion plants. This curvature due to the negative geotropism, which occurs when the product is placed horizontally (shehata et al., 2010). As shown in Table 5 there is an announced increase in the stem curvature as the storage period prolonged. This result agreed with (shehata et al., 2010). Concerning treatments, stem curvature was completely controlled in all tested treatments for 5 days storage at $3 \pm 1^{\circ} \mathrm{C}+95 \% \mathrm{RH}$. The stem curvature of all treated green onion plants began to appear after 10 days of storage, and efficiently increased until 15 days storage, as compared with non hydro-cooled and non packed (control) plants. The interaction between treatments and storage periods reveal that, non hydro cooled and non packed treatments effectively controlled stem curvature of green onion as compared with other treatments.

\section{Leaf extension and root development:}

Data in Tables 5and 6 demonstrate the effect of our tested treatments on the leaf extension and root development of green onion plants during storage at $3 \pm 1^{\circ} \mathrm{C}+$ $95 \% \mathrm{RH}$. The statistical analysis shows an obvious increase in both leaf extension and root development as the storage period extended. This result was in harmony with (Shehata et al., 2010).The increase in leaf extension and root development of green onion plants may be due to the postharvest growth phenomena of green onion (Hong et al., 2000).

In respect to treatments, all tested treatments efficiently retarded leaf extension and root development to the minimum limited value for leaf extension $(5 \mathrm{~mm})$ and $(3 \mathrm{~mm})$ for root development in both seasons.On contrast, non hydrocooled and packed condition, stimulated leaf extension and root development in both 
seasons. The interaction between treatments and storage periods showed that, non hydro-cooled and packed treatment recorded the highest leaf extension and root development.

\section{TSS\%:}

It is clear from Table 6 that TSS\% of green onion declined during storage. This decrease may be attributed to the consumption of simple acids and sugars during respiration Atta-Aly (1998). The same Table reveals that our studied treatments effectively maintained the TSS\% without pronounced difference between them as compared with non hydro-cooled and non packed treatment (control) in the first season. Meanwhile, hydro-cooled and packed treatments recorded the highest TSS\% as compared with the other treatments. This result was in line with the work of AttaAly (1998) on green onion. On the other hand, non hydro-cooled and non packed green onion recorded the lowest values of TSS\% in both seasons. The interaction between treatments and storage period displayed that hydro-cooled and packed treatments maintained green onion TSS $\%$ for 15 days of storage at $3 \pm 1^{\circ} \mathrm{C}+95 \% \mathrm{RH}$ in both seasons.

\section{Chlorophyll content:}

Data presented in Table 6 show the chlorophyll content of green onion plants as a SPAD reading. As shown in the Table, a progressive and a significant decrease happened in chlorophyll content as the storage period was prolonged. Generally, green onion plants became yellowish green with the extension of the storage period. Regarding treatments, it is clear from the results that Hydro-cooling and packing green onion plants in polypropylene bags significantly reduced chlorophyll degradation of green onion leaves comparing with other treatments. These results were in agreement with the findings of (Atta- Aly 1998, Niyomlao et al., 2000, and Alvares et al., 2007). Meanwhile, no significant differences was detected in chlorophyll content between hydro-cooled and non packed and non hydro-cooled and packed green onion plants in the first season. Moreover, control plants (non hydro-cooled and non packed) recorded the lowest SPAD value of chlorophyll content. This result seems to be in harmony with Atta- Aly (1998) who found that leaves wilting and yellowing was positively correlated with water loss. And also, higher humidity levels and low temperature may be negatively affected ethylene biosynthesis and leaf yellowing. The interaction between treatments and storage periods indicated that, the combination between hydro-cooling and packaging had a beneficial effect on the retention of green onion plants with vivid green color. 
Table 5 . Effect of hydrocooling and packaging on curvature and leaf extension of green onion during storage period in 2014/2015 and 2015/2016 seasons.

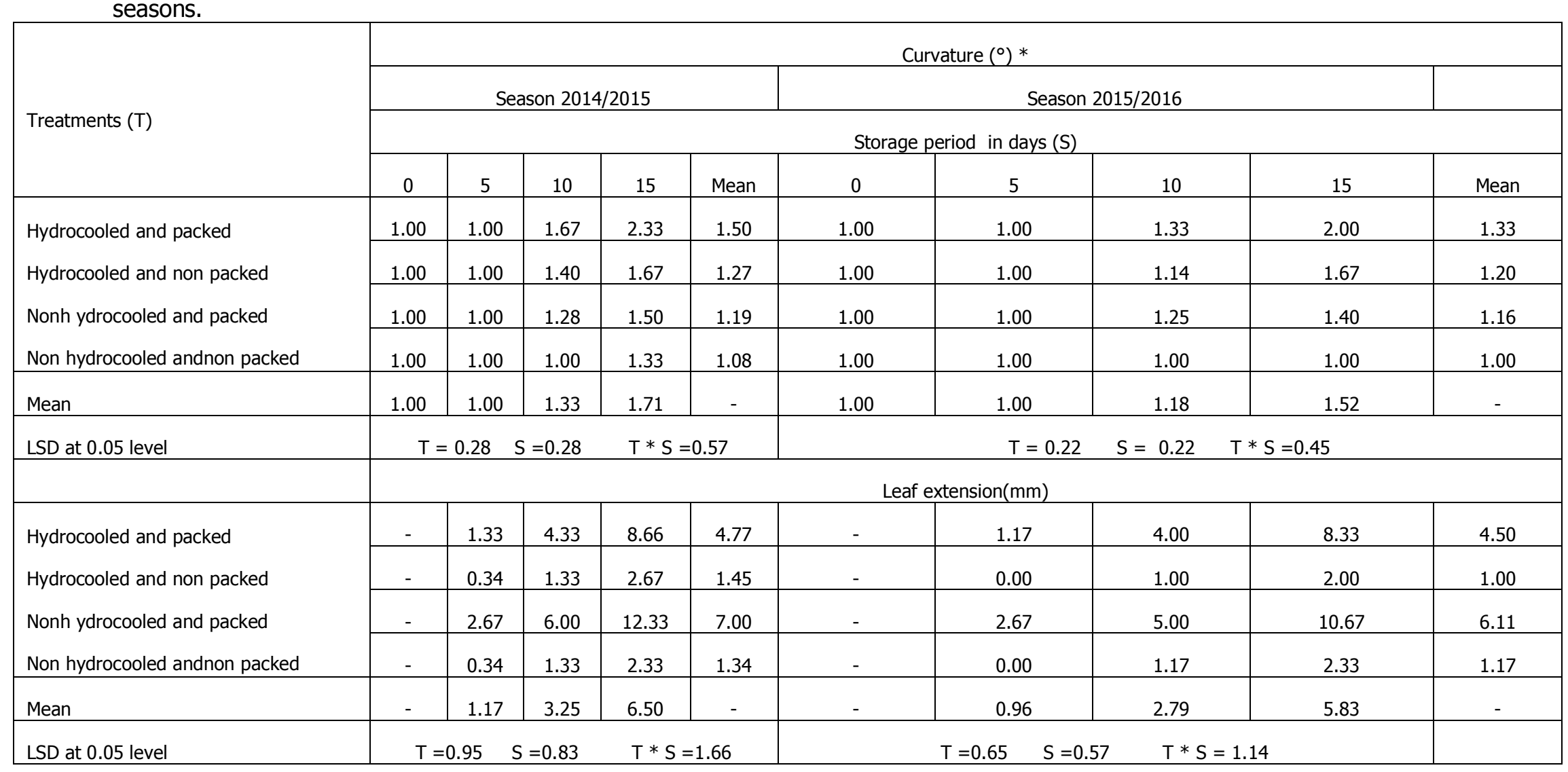

$* 1$, none; 2 , curvature of stem or leaf up to $15^{\circ}$ from the horizontal, $3=15-30^{\circ}, 4=30-45^{\circ}$ and $5>45^{\circ}$ 
Table 6 . Effect of hydrocooling and packaging on root development, TSS\% and chlorophyll content (SPAD unit) of green onion during storage period in 2014/2015 and 2015/2016 seasons.

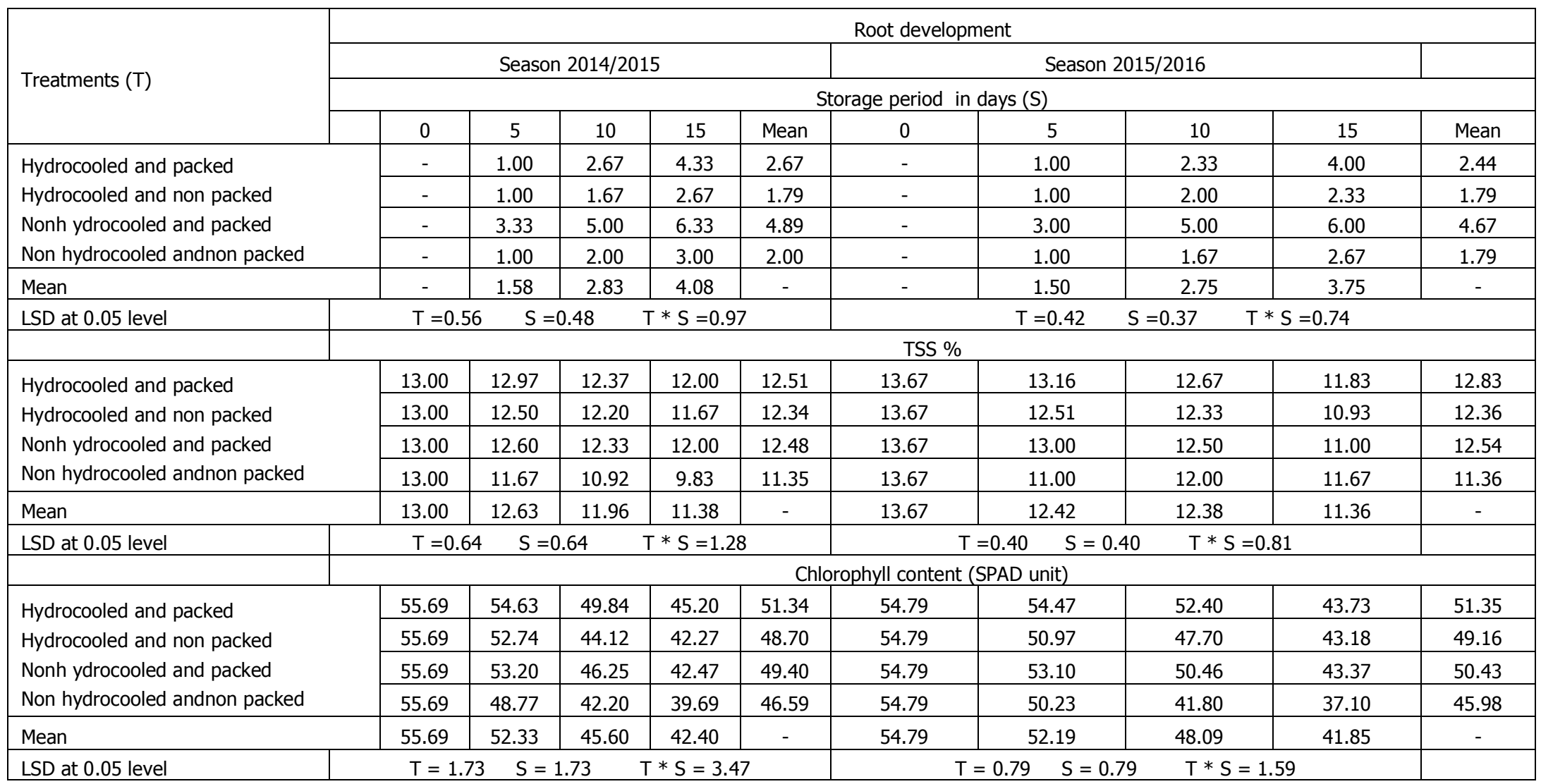




\section{CONCLUSION}

The present work indicated that sowing green onion seeds at low density $5 \mathrm{~cm}$ on one side (33 plant $/ \mathrm{m}^{2}$ ) significantly increased plant weight, bulb diameter, and total dry weight per plant in both seasons of study as compared to other treatments. Meanwhile, higher plant density $2.5 \mathrm{~cm}$ on both sides $\left(133\right.$ plant $\left./ \mathrm{m}^{2}\right)$ significantly increased total yield per fed., Regarding, storage experiment, the obtained results showed, that the combination between hydro-cooling and packaging, effectively maintained green onion plants with fresh appearance and acceptable sensory quality for 10 days at $3^{\circ} \mathrm{C} \pm 1$ and $95 \%$ RH.

\section{REFERENCES}

1. A.O.A.C. 1990. Quality of Official Analytical Chemists $15^{\text {th }}$ ed. Washington DC. USA.

2. Alvares, V.S. F. L. Finger, R.C. A. Santos, J. R. S., Negreiros, andV. W. D. Casali. 2007. Effect of pre-cooling on the postharvest of parsley leaves. Journal of food Agriculture and Environment 5(2):31-34.

3. Atta-Aly, M.A. 1998. Effect of hydrocooling and polyethylene package lining on maintaining green onion quality for export. Annals Agric. Sci., Ain Shams Univ., Cairo, 43 (1): 231-249.

4. Brewster, J. L. 1994. Onions and other vegetable Alliums. CAB International, Wallingford, UK.p236.

5. Dahmardeh, M., M. Ramroodi and J. Valizadeh. 2010. Effect of plant density and cultivars on growth, yield and yield components of faba bean (Vicia faba L.). African j. Biotechnol. 9(50): 8643-8647.

6. El-Seifi, S. K., S. M. Hassan, A. H. Amer and E. M. Khairy 2014. Effect of plant population and sowing dates on growth and yield of dry bean (Phaseolus vulgaris, L.) 1- Plant growth and yield. J. plant production, Mansoura Univ., 5(7): 1143-1156.

7. Emam,M.S. 1999. Effect of some postharvest treatments on the storage and quality of green onion.phD. Thesis fac, of Agric. Ain shams Univ.

8. Fricke, B. A. 2006. Pre-cooling fruits and vegetables. Ashrae journal 48: 20-28.

9. Hong, G., G.,Peiser and M. I. Cantwell. 2000. Use of controlled atmosphere and heat treatment to maintain quality of intact and minimally processed green onions. Postharvest Biology and technology, 20:53-61.

10. Hussen, S., F. Medhinbs and A. Tadessecs. 2014. Effect of intra-row spacing on growth performance of garlic (allium sativum) at the experimental site of wollo university, south wollo, Ethiopia. European J. Agric. And Forestory Res. 2(4):5461. 
11. Kader, A.A. 1986. Modified atmosphere packaging of fresh produce. Outlook Second Quarter 13: (2):9-10.

12. Kahsay,Y., D. Belew and F. Abay. 2013. Effect of intra-row spacing on yield and quality of some onion varieties (Allium cepa L.) at Aksum, Northern Ethi. African J. of Plant Sci. 7(12): 613-622.

13. Kantona, R.A.L., L. Abbeyb, R.G. Hillac, M.A. Tabil and N.D. Jane. 2003. Density affects plant development and yield of bulb onion (Allium cepa L.) in Northern Ghana. J. Veg. Crop Prod. 8(2):15-25.

14. Kitinoja, L. and J. F. Thompson. 2010. Pre-cooling systems for small-scale producers Stewart Postharvest Review. 2(2):1-14

15. Niyomlao, S. K. and C. Maneerat. 2000. The Effects of Hydro-cooling and Plastic Bag Packaging on the Shelf Life of Chinese Kale (Brassica albograba L.) Quality assurance in agricultural produce, edited by G.I. Johnson, Le Van To, Nguyen Duy Duc and M.C. Webb.ACIAR Proceedings 100.

16. Om, H. and R.p. Serivastava. 1977. Influence of the planting material and spacing on the growth and yield of garlic. Indian J.Hort. 34(2): 152-156.

17. Rahman M. M., MD. Miaruddin, MD. G.F., Chowdhury,MD.H. H., Khan and M.A. MATIN. 2012. Effect of different packaging systems and chlorination on the quality and shelf life of green chili. Bangladesh J. Agril. Res. 37(4): 729-736.

18. Shehata,S.A., M.S.Hasehm.,M.A.Rageh., and M.M.Attia. 2010. Effect of heat treatment on quality attributes of fresh -cut green onion during cold storage.Annals of Agric.Sci., Moshtohor, 48(2):Ho.149-158.

19. Singh,S.R. and B.P.Sachan. 1999. Interaction of bulb size and spacing on seed yield and yield attributing trait of onion (Allium Cepa L.) Scientific Horticulture, 6: 126-128.

20. Snedecor, G. W. and W. G. Cochran. 1980. Statistical Methods. 7th Ed. The Iowa State Univ., Press, Amer., Iowa, USA .

21. Steven, A.S, M.T., Talbot, and J.K. Brecht. 1988. Evaluating precooling methods for vegetable packing house operation. Proc. Fla. StateHort. Soc.101:175-182.

22. Sullivan, G.H., L.R. Davenport and Julian, J.W. 1996. Precooling: key factor for assuring quality in new fresh market vegetable crops. P. 521-524. in J. Janick, ed. Progress in new crops. ASHS Press, Arlington, VA.

23. Technical bulletin. 2004. Green onion Postharvest Care and Market Preparation Ministry of Fisheries, Crops and Livestock New Guyana Marketing Corporation National Agricultural Research Institute.

24. Wanns, M.N. J., D. H. Denes and R.J. Barcen. 1986. Effects of planting density and design on pod yield of bush snap bean (Phaseolus vulgaris L.). Canadian J. Plant Science, 66: 669-675. 


\section{تأثثير بعض معاملات ما قبل وما بعد الحصاد \\ على الجوده والقدره التخزينيه للبصل الاخضر}

\section{أميمة عثمان محمد - أمل سيد حسن عتريس}

$$
\text { قسم معاملات ما بعد الحصاد و تداول الخضر - معهز بحوث البساتين - مركز البحوث الزراعبة - مصر }
$$

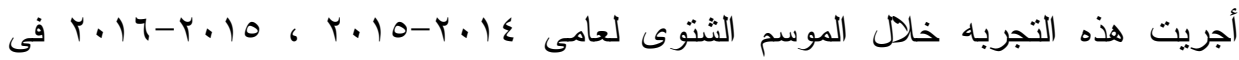
المزرعه البحثيه التابعه لمعهذ بحوث البساتين بالقصاصين بمحافظة الاسماعيليه - مصر، وذللك

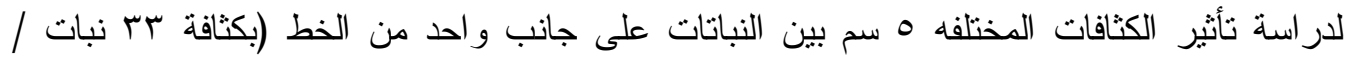

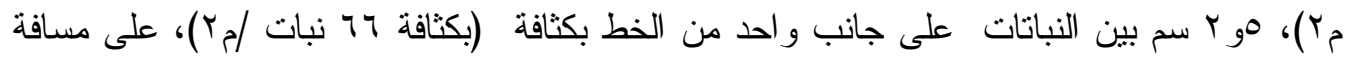

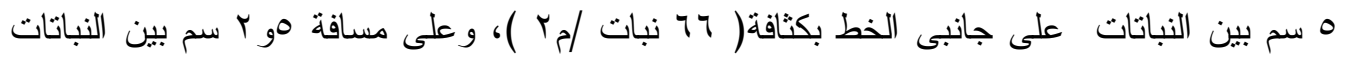

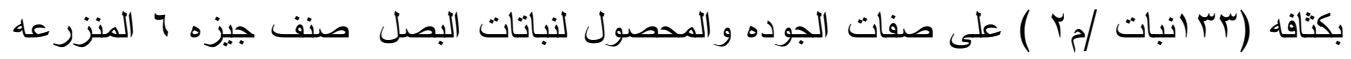

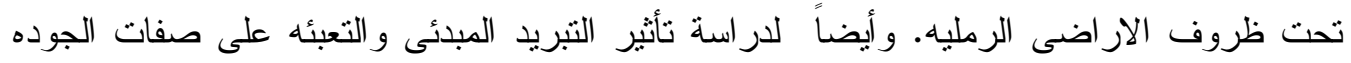

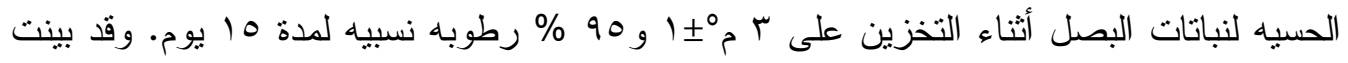
النتائج المتحصل عليها أن زر اعة نباتات البصل بكثافه منخفضه على مسافة هسم بين النباتات على ولى

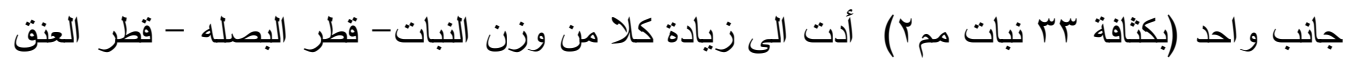

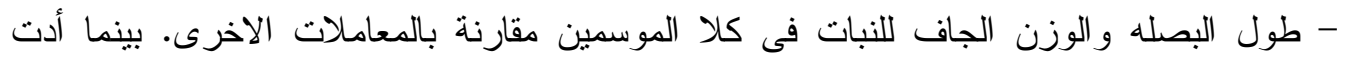

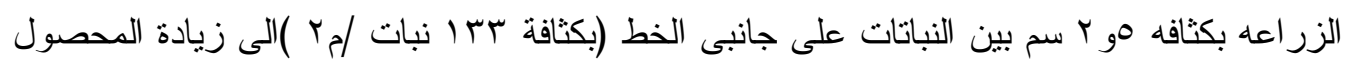

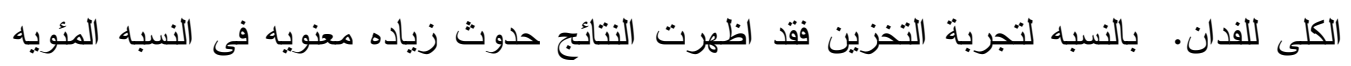

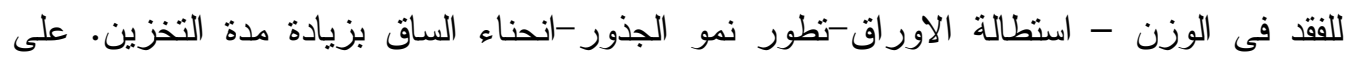
الجانب الأخر حدث انخفاض فى المظهر العام و المحتوى من الكلوروفيل والنسبه المئويه للمواد

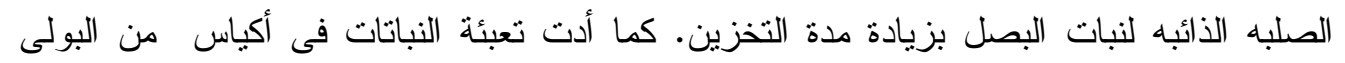

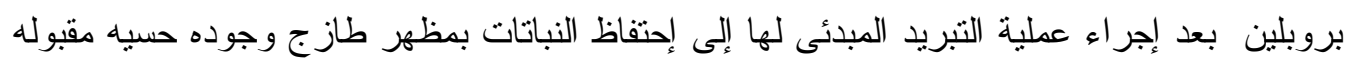

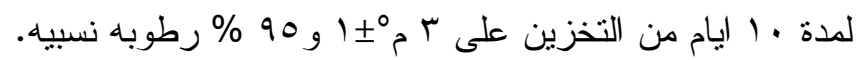

